\title{
Chien-wen Kou and Xiaowei Zang (eds), Choosing China's Leaders,
}

London, New York, Routledge, 2013, 166 pp.

Jérôme Doyon

Translator. N. Jayaram

\section{OpenEdition}

12 Journals

Electronic version

URL: http://journals.openedition.org/chinaperspectives/6664

DOI: 10.4000/chinaperspectives.6664

ISSN: 1996-4617

Publisher

Centre d'étude français sur la Chine contemporaine

\section{Printed version}

Date of publication: 1 March 2015

Number of pages: 63-64

ISSN: 2070-3449

\section{Electronic reference}

Jérôme Doyon, « Chien-wen Kou and Xiaowei Zang (eds), Choosing China's Leaders, », China

Perspectives [Online], 2015/1 | 2015, Online since 01 January 2017, connection on 24 September 2020 URL : http://journals.openedition.org/chinaperspectives/6664 ; DOI : https://doi.org/10.4000/

chinaperspectives.6664 
(1995), new industrialised countries (NICs) of East Asia (1997), Brazil (1999), Argentina (2001), and more recently southern European countries. It seems to confront several political and social weaknesses - above all economic that affect all these countries at special but different levels, which underline again the extreme heterogeneity of national situations grouped under the convenient but nevertheless rather irrelevant acronym BRICS.

By separating China from Chinese studies, the author has contributed a salutary work. This is similar to other observers such as Arif Dirlik, who see the Chinese economic structure as an immense enterprise where about $20 \%$ of the population exploits the rest of the billion, most of whom are often condemned to surviving on the margins and often in great precariousness (migrants, the elderly, rural populations, and unemployed graduates). (2) The absence in the otherwise impeccable bibliography of the works of Dirlik, as well as of other authors such as Maurice Meisner, who has also reflected on the future of socialism in China, is surprising and regrettable. Gaulard's book can be counted among economic literature on China that leans more towards the problems of the "Chinese model" than on developmentalist successes of forced productivism. However - and this is where the book becomes problematic - torn between political economy and intellectual history, it seems to divide people into "vulgar economists" and "uncouth Marxists," the author leaving herself little room for being heard by experts on Chinese economy and those engaged in Chinese studies in general. And the deliberately iconoclastic and polemical - even mocking - tone, which lends the book a freshness in the often arid domain of economics, could attract a knee-jerk, ideological reaction that would miss the point and prevent a thoughtful response to an otherwise fine and eloquent work that makes for fascinating reading and which, it is worth repeating, has great pedagogic and intellectual qualities.

I Translated by N. Jayaram.

I David Bartel is a PhD candidate with CECMC, EHESS, Paris and doctoral associate with CEFC (db.chine@gmail.com).

2. Arif Dirlik (interviewed by Luciana Leitao), "Chinese Communist Party - World's Biggest Corporation," Macau Business Daily, 25 June 2013.

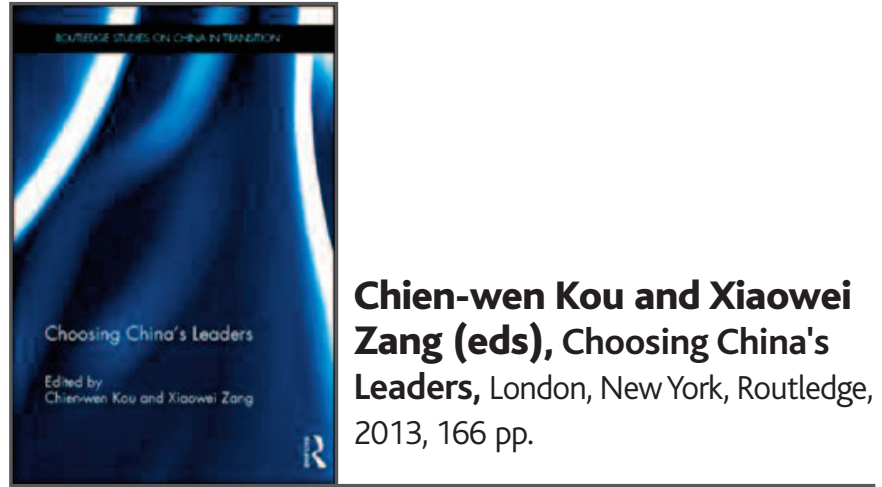

\section{JÉRÔME DOYON}

1 his book emerged from a conference focusing on Chinese political elites held in November 2010 at National Chengchi University in Taipei. The book has the merit of, among others, rendering accessible in English the rich work on the Chinese party-state by Taiwanese scholars, who account for six of the nine contributions. While varied approaches have been adopted, the authors share a distancing from classical Pekinology, which sheds light on day-to-day goings on behind Zhongnanhai walls, and a preference for focusing on the issue of Chinese elites in a dynamic manner, concentrating on the mechanisms at work in the modes of promotion and exercise of power by the Chinese leadership. As the introduction by Chienwen Kou and Xiaowei Zang shows, the book as a whole is concerned with current debates on factions and on the technocratisation and institutionalisation of the Chinese Communist Party (CCP). Its ambition is to go further than existing literature, mostly Anglo-Saxon, by detailing the interactions between informal networks and the Party's institutionalisation. According to Kou and Zang, two phenomena that are generally ill understood are: the causes and forces behind the Party's institutionalisation, understood as the development of rules governing the recruitment, promotion, and exit and retirement of cadres; and the interaction between this phenomenon of institutionalisation and the survival of factionalism and nepotism.

The first two contributions concern national political elites. Hsin-hao Huang studies the careers of members of the CCP Central Committee's Politburo from 1997 to 2007 . He uses a method that stems from a qualitative-quantitative comparative analysis by applying statistical tests to a very limited sample of political careers. He sheds light on the persistence of "informal" political practices in the sense that they are not governed by organisational rules in the framework of a growing institutionalisation of promotion regulations in the Party. Adoption of rules concerning candidates' age, gradual promotion of cadres, and the practice of transferring them from one branch of the partystate to another have led to a standardisation of the careers of Politburo members. Following is the typical-ideal candidate for a Politburo seat: 63 years old, a Central Committee member, and with much experience in ministerial posts. The candidates' age limit pushes functional chiefs to promote their protégés as speedily as possible in order to ensure their succession. In Huang's view, getting promoted very young is thus a sign of a developed personal network. While the reasoning is interesting, it nevertheless seems difficult to analyse age at promotion purely in light of a cadre's personal relations when it could be due to many additional factors, including his or her personal competence.

Using a more qualitative approach, You ji's contribution examines changes in the promotion of military officers in the context of the professionalisation of the army. He highlights the development of a meritocracy in the People's 
Liberation Army. Selection methods have become increasingly competitive, consisting of written and oral examinations evaluated by cadres drawn from different departments in order to avoid personal collusion. "Informal" practices are resorted to at the candidates' pre-selection stage, when only three are considered for each post. Personal links become crucial, as candidates need to be recommended by an officer. According to You Ji, officers conveniently pick those in their own combat units or from the same province.

The next two contributions deal with provincial elites. Bo Zhiyue charts the careers of 31 provincial Party secretaries and governors as of November 2012 , showing that the tendency is towards a relatively strict adherence to age limits as well as qualification levels for posts as heads of provinces. $\mathrm{He}$ notes the need for varied experience in different sectors in order to be named a provincial secretary. While Bo also describes the cadres' supposed factional attachments, he fails to explain what effect they could have in practice, or possible changes.

In the second chapter devoted to provincial elites, S. Philip Hsu and Jhihwei Shao evaluate the level of meritocracy in the cadre promotion system. Their analysis relies on dates, including all provincial Party secretaries and governors between 1993 and 2010. Contrary to previous studies, they show that work experience at the central level is generally not a good indicator for promotion to the top rung in a province, but rather is a sign of approaching retirement. At the same time, the authors show that provincial chiefs are evaluated via a complex system taking into account their short-term economic performance in deciding whether they can keep their post, but also their cumulative results over the long term, compared with their predecessors, in considering them for promotion.

The book's last two chapters are devoted to specific elite types: state enterprise managers and cadres rising through the CCP Youth League. In each case, the authors seek to measure the effect of this experience on their future careers. Chih-shian Liou and Chung-min Tsai describe the CCP's control over major state enterprises via the selection and promotion of their managers and find that those who are aligned with the Party-state's agenda are promoted. In their view, the effects on future careers vary according to industrial sectors. Liou and Tsai, for instance, show that in electrical industry, promotions take place mainly within the sector, but that in the more strategic oil sector, managers can hope for political posts with great responsibility following their industrial careers.

In the last chapter, Chien-wen Kou deals with the careers of cadres who worked in the Communist Youth League after 1978. Charting the careers of 293 individuals, he notes the importance of this promotion channel, pointing out its two main features. First, few former Youth League cadres hold technical or economic ministerial posts, indicating that the League consists of generalists. Then again, League experience gives them an age advantage, helping them get important posts while still young compared to other cadres - a major career advantage. Apart from these two factors, Kou notes that the rapid and numerous promotions of former League cadres is also due to the organisation's strong links with key Party figures such as $\mathrm{Hu}$ Yaobang in the 1980s, then with Hu Jintao and later Li Keqiang. While the argumentation seems sound, might Kou not have overplayed the role of the organisation's internal network and by extension the unity of the faction at issue? As he has himself notes, the selection of the League's cadres at all levels rests with CCP organs and not with the organisation itself, calling into question the homogeneity of its recruitment.

To conclude, Choosing China's Leaders should interest all readers curious about the process of selecting Chinese political elites. It has the classical lacuna of collective works in that issues raised in the introduction are only partially addressed in the chapters that make up the book. More generally, while the book has on the whole focused on the interaction between the Party's growing institutionalisation and the persistence of entrenched factions, this separation between policies seen as "formal" or "informal" has not been addressed. The question might well arise whether their constant interaction does not challenge this dichotomy. Personal relations also tend to be treated as a given, without proper questioning of the mechanisms explaining their development and persistence. A more dynamic approach to these networks would thus be welcome for a clearer understanding of promotion mechanisms in the Chinese Party-state.

\section{Translated by N. Jayaram.}

I Jérôme Doyon is $\mathrm{PhD}$ candidate in political science at SciencesPo/CERI, Paris, and Columbia University, New York (Jd2988@columbia.edu).

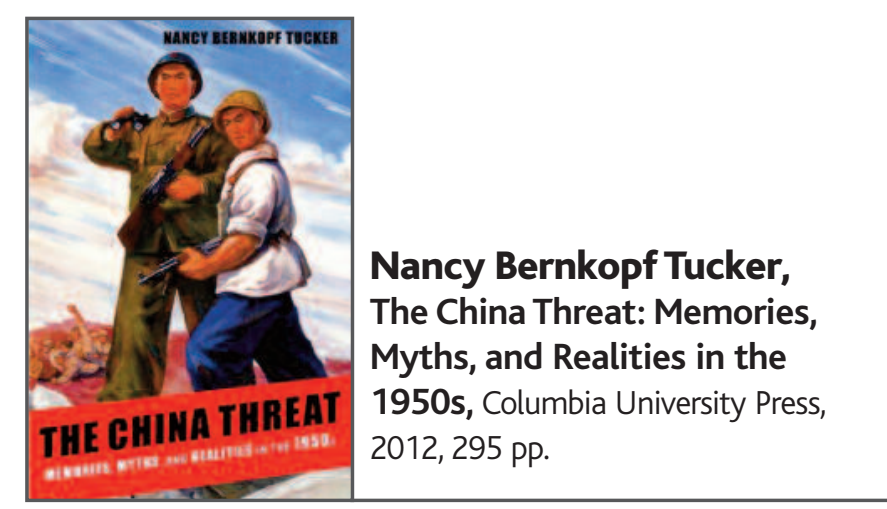

\section{EDWARD FRIEDMAN}

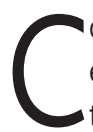
ompleted during her final battle with cancer, this book by the preeminent American diplomatic historian of PRC era USA-PRC relations, Nancy Bernkopf Tucker, is a superb study of Eisenhower era Washington-Beijing relations. She finds that President Eisenhower, Ike, erred when he concluded that political forces in his Republican Party, the U.S. Congress and American public opinion made it impossible for him to act on his personal views that a constructive approach to Mao's China was preferable to an unsustainable policy of trying to isolate a stable CCP regime from international organisations and trade.

For Tucker, Ike should have educated the American public to understand that a powerful PRC was here to stay and also should have made overtures to Mao toward normalising relations. Tucker will not accept what her data establishes, that American politics blocked such policies.

Tucker challenges myths about Eisenhower's policy on the PRC. Her archival digging and interviews with key American actors undermine the story that Ike's successor, John Kennedy, could not open to China because Ike had threatened to rally the people against Kennedy attempting such an opening. Tucker shows that Eisenhower actually wished to end the doomed policy of trying to isolate the PRC.

"The China Threat" also clarifies why the Eisenhower administration got so many things wrong about China. Tucker details why the U.S. administration would not believe the data showing a Moscow-Beijing split and how the administration wrongly saw Mao's economically irrational policies as 